\title{
Problems and Challenges Faced by EFL Students of Saudi Arabia during COVID-19 Pandemic
}

\author{
Tawhida Akhter \\ Assistant Professor, Department of English, College of Sciences and Languages Sajjir, \\ Shaqra University, Kingdom of Saudi Arabia, Email: tawhida@su.edu.sa, ORCID ID: oooo- \\ ooo3-4149-4855
}

\begin{abstract}
The teaching of English as a Foreign Language (EFL) is very interesting but at the same time is considered difficult particularly for those students who have read most of the subjects of their courses in their mother tongue. The four skills viz, Listening, Speaking, Reading and Writing are necessary for learning a foreign language and an imbalance in any skill can hamper the whole process. All the skills are important but during present pandemic situation listening skill is considered as a problematic skill particularly in a foreign language context where practice opportunities are limited because of the world pandemic COVID19 that hampered all our teaching and learning process. This study aimed to explore the problems and challenges faced by EFL students because of the limited resources. An online survey method was followed to collect data from a group of Saudi EFL students $(n=100)$ using the Listening Comprehension Processing Problems Questionnaire. The results indicated that these students experienced moderate to high levels of difficulty in all the skills particularly in 'Listening' because of limited resources. The findings are expected to have useful implications for teachers who intend to address these problems of EFL learners. Analysis of the findings revealed that most of the students encountered problems in listening most of the times during online classes sometimes because of physical and sometimes other barriers. Discussion and implications of these findings are presented.
\end{abstract}

Keywords: EFL language learning, listening, speaking, reading, writing, COVID-19, online teaching problems.

\section{Introduction}

In the context of the COVID-19 pandemic and government strategy for electronic teaching and learning, the purpose of the current research is to explore how EFL learners carry out EFL learning and what are problems and challenges faced by them. Corona-virus disease 2019 (COVID-19) emerged from the People's Republic of China's Hubei Province and has been declared as a global pandemic worldwide by WHO. This virus has infected most of the countries all around the globe. In 11 March 2020, the Ministry of Education in accordance with the Ministry of Health, the Government of Saudi Arabia suspended class-work in all schools, colleges and universities in order to limit the spread of COVID-19 infections. This global pandemic caused class suspension and resulting in the demand of online learning throughout the Kingdom.

Such initiatives lead to students studying from home and also teachers working from home. It completely replaces face-to - face learning in the classroom setting with online learning,

(C) AesthetixMS 2020. This Open Access article is published under a Creative Commons Attribution Non-Commercial 4.o International License (http://creativecommons.org/licenses/by-nc/4.o/), which permits non-commercial re-use, distribution, and reproduction in any medium, provided the original work is properly cited. For citation use the DOI. For commercial re-use, please contact editor@rupkatha.com. 
which due to the COVID-19 pandemic may last until the end of the semester. The challenges of online learning are a fresh obstacle for students and teachers alike. This behaviour, according to Cao et al (2020), definitely has an effect on education, particularly the growth of the students. So far, there are a variety of online learning studies mainly in the ESL sense. In the EFL sense, however, none of the studies were performed, especially in terms of Learners' experience of utilizing online learning in the midst of the covid-19 pandemic. The COVID-19 pandemic had a major effect on human survival around the globe. Indeed, the Covid-19 pandemic could trigger the global economy to compress to one quarter by 2020. The Corona Virus also affected the field of education also.

As per the UNESCO, Corona virus epidemic had an influence on the education field. About 300 million students globally disrupted their academic practices and have to go for online learning. Most of the countries suspended schools across the country in an attempt to stop the virus spreading. Teaching- learning tasks that had traditionally been carried out in the school through face-to - face approach moved to the electronic learning program. The idea of social distancing and physical distancing needs that everybody remain home, so that this epidemic will not propagate. Therefore, all teachers and students are required to sit at home and also perform their responsibilities and duties as usual. To keep students aware regarding proper education and teaching, teachers are expected to be more creative and inventive. Thus the teachers in Saudi Arabia used E-Campus application and other applications like Zoom, Google Classroom and other teaching platforms to teach their students. E-learning goes on to spread worldly since teachers and students feel comfortable and possibility in setting up and accessing opportunities to teach alternatively (White, 2008).

Despite the COVID-19 pandemic and government policies to be applied, online learning that allows students to study from home and teachers to teach from home as well, this work examines how EFL learners conduct EFL learning online and what obstacles they encountered and the possible explanations for doing so. Drawing on evidence from college students related to the online language learning study of different colleges in Saudi Arabia. It enriches the awareness of how Saudi Arabia's EFL learners conduct EFL learning online in a sudden and totally unprepared circumstance owing to the COVID-19 pandemic. It also sheds some attention on the obstacles they encountered during their online learning activities. So the objective of this research from that perspective is to explore the impression of the learners on online learning in the midst of a COVID-19 pandemic.

\section{Methodology}

This study applied qualitative approach as Creswell (2014) notes that it is important to use qualitative analysis to apply to work focused on empirical evidence that does not (regularly) utilize statistical procedures. The subject of this research is the EFL learners of English study program of Saudi Arabia. The instrument used is semi-structured interview the researcher interviewed the learners by calling them by using WhatsApp application and by using online Google Forms. Six phases are used in the process: familiarization, creating initial codes, looking for themes, updating themes, identifying and naming themes, and reporting.

\section{Participants}

The participants were 100 EFL learners consisting of different colleges of Riyadh Province in Saudi Arabia. All these are enrolled for various EFL courses. 


\section{Data collection}

100 EFL learners (grouped as L $1-L$ 10), the students were divided into ten (10) groups ( $L=10$ students) volunteered by invitation to become participants in the study. EFL learners were invited to create written comments on their experiences in pursuing online EFL learning and the difficulties they face while going through the course of online teaching learning. Semi-structured interviews with every interviewee were conducted and took place for around 30 minutes.

Participants were invited to provide comprehensive information regarding learning processes, electronic learning resources used, and examples of content, quizzes, tasks, as well as projects provided to students to represent the electronic EFL learning activities that they performed during the COVID-19 pandemic, as described in the written reflections. The learners were also guided to discover the difficulties they faced during the COVID-19 pandemic in undertaking online EFL instruction, and to uncover legitimate explanations behind them. Both conversations were recorded and transcribed in audio format to be more analysed. Until the study was done, consensus was gained from all the researchers. Interview excerpts have been read many times to get initial aspects of the online EFL learning practices and their difficulties. Coding of data was undertaken in order to show recognition and evolving patterns. It also deleted redundant and unimportant records.

\section{Results and Discussion:}

The EFL learners' perception on online learning during COVID-19 pandemic- This research aims at exploring the experience of the learners on the Online Learning Network in the wake of a COVID-19 pandemic. Below are the findings of the review of data gathered from the interviews and online Google form collected from EFL learners.

\section{Online learning during COVID-19 Pandemic}

The application of the online learning system in the centre of pandemic brought about the various reactions and perceptions of the student Program English studies of Saudi Arabia. The form Zoom, Google Classroom and Learning Management System used in the Saudi Universities is an e-campus program. Here are the Learners' perceptions of using that LMS and other online platforms in Literary Criticism class of level 7 students:

L 1: We believe teacher, online coursework is perfect enough that we are focused on something at home, just a challenge if there is a coursework so there is no room for lecture or discussion. Furthermore, there is a network and web limit that some students can have connectivity problem.

L 2: No issue teacher but less able to connect effectively because sometimes the internet is bad and network becomes irritating at times.

L3: No problem with online learning but the network and Internet data is a problem.

L 4: No issues with e-learning platforms but internet and network problems are often obstacles while teaching learning process is going on.

L 5: Only connectivity issues that is an obstacle in the development of Listening skill. 
L 6: Adaptability struggle and poor network because switching from traditional teaching to online teaching makes learning entirely different for the students.

L 7: Technical issues are the main obstacles in online learning. The weak internet bandwidth makes it hard to follow the Course Management System and makes their learning problematic.

L 8: Computer Literacy is an obstacle as most of the students are not familiar with different types of soft-wares and face problems in online teaching learning. Many of the students are not able to operate programs like Microsoft Word, Power point and thus are not able to handle their files.

L 9: Time management is an obstacle in online teaching for learners.

L 10: Connectivity and Self motivation.

Some of the common obstacles that every student faces are mentioned below:

\section{1) Limited experience in technology:}

Some online learners may hesitate to move into e-learning because they have little tech experience. They have learned that e-learning is not for tech-savvy people, so they have so far ignored it. That is one of the obstacles to leap through since it's a pre-existing assumption. Online learners have become convinced they need advanced tech skills to participate. But we as a teacher can alleviate their fears by supplying them with online tutorials and customized assistance.

\section{2) Past Experience:}

For eLearning not everybody has amazing previous experiences. That is why they are now dreading it. It refers particularly to online learners who have had to undergo repetitive online training courses for compliance. You can't remove the past, but in the new eLearning plan you can get them ready. Online learners who have had bad experiences need no more, and particularly unpleasant, surprises. So, be clear about why the eLearning course should be taken, and how it will improve their lives. In addition, perform polls and questionnaires to identify areas of problem that need to be addressed. Problems associated with certain eLearning classes, for instance.

\section{3) Feeling unmotivated}

You even already realized the inspiration was about to appear at the top of this thread. It's one of the most important obstacles confronted by eLearning practitioners, after all. The loss of encouragement will lead to any variety of issues. But there is a way to include and positively participated the online learners in the process like badges, awards, certificates, points give elearners the motivation they need to achieve the desired outcomes.

\section{4) Personal Cognitions:}

Unfortunately, some of our online learners may be dealing with beliefs and opinions that defy themselves. For starters, they may feel like they don't have the expertise or abilities to participate in our eLearning course. This stops them from having the advantages of the e-learning program that we are providing. Acknowledging and evaluating these is one of the best ways to overcome personal cognitions. Ask online learners questions that are thought-provoking and inspire them to discuss their views and perceptions. 


\section{5) Insufficient Support}

Many of the online learners can be breezing themselves into the eLearning programme. They don't need any additional help, and they can easily navigate the eLearning course. And there are those who need continuing support during the entire e-learning process. Using the Learning Management Program these learners may not be confident or consider the subject hard. Whatever group online learners fall under, they will have access to help. Provide them with a list of contact details and links to online tools which they may use to enhance their comprehension.

\section{6) Technical Issues:}

Many students do not have the high bandwidth or the strong internet connection required by online courses, and thus fail to meet their virtual classmates: their weak monitors make it difficult to follow the course management system and their learning experience becomes problematic. In addition, most of them live off-campus and find it difficult to stick to the technical requirements of the course chosen. Many of them don't yet possess devices and are finding technological support from Learning Support Centres. The only solution to this dilemma is to realize precisely what kind of technical assistance they would require for a certain course before enrolling in it, and to prepare them appropriately for effective completion of the course.

Fig. 1

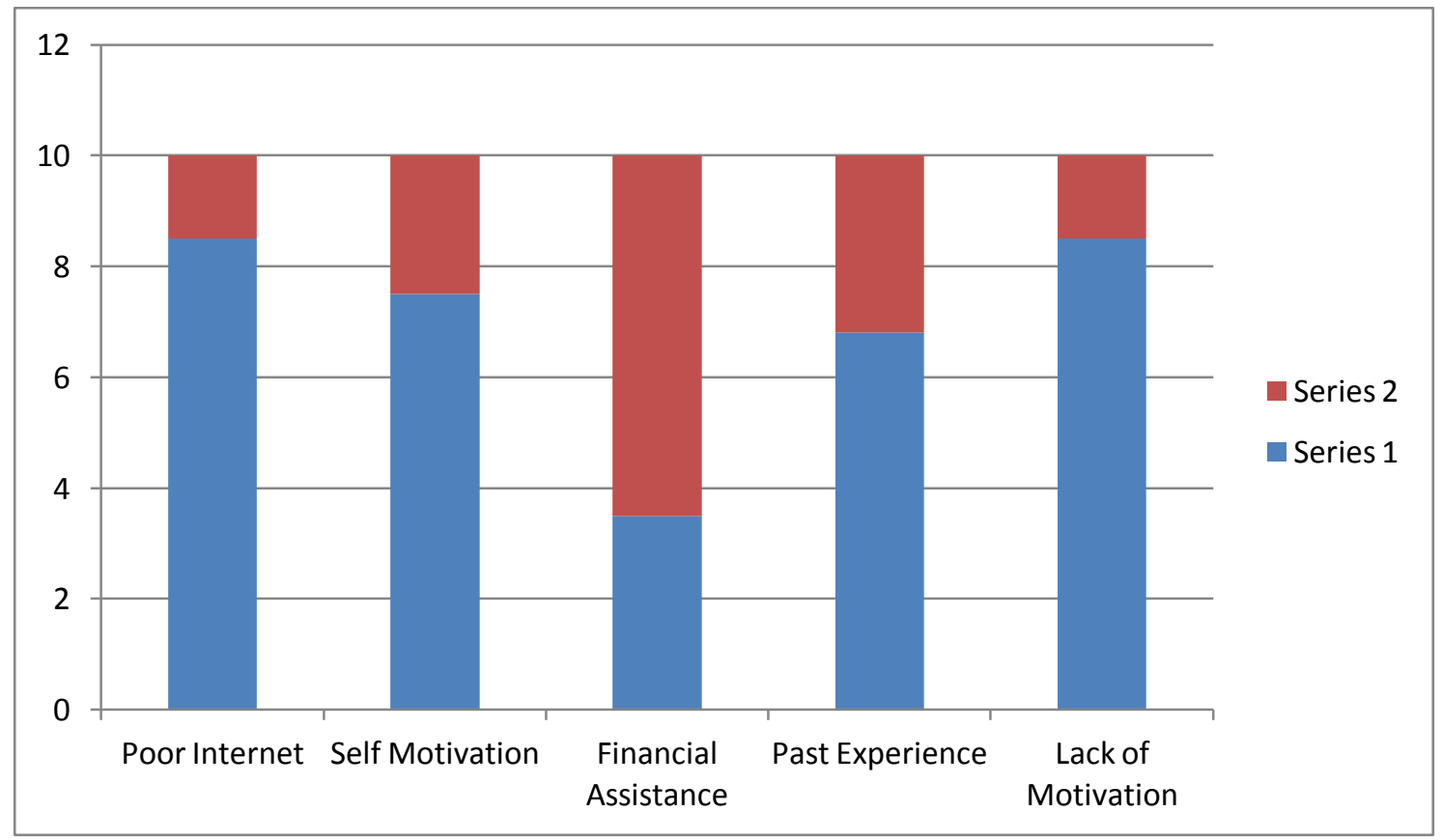

Table Showing the Challenges faced by EFL learners

Fig. 2 The following chart shows that how an EFL teacher can motivate his learners towards online learning and makes it an interesting for them. 


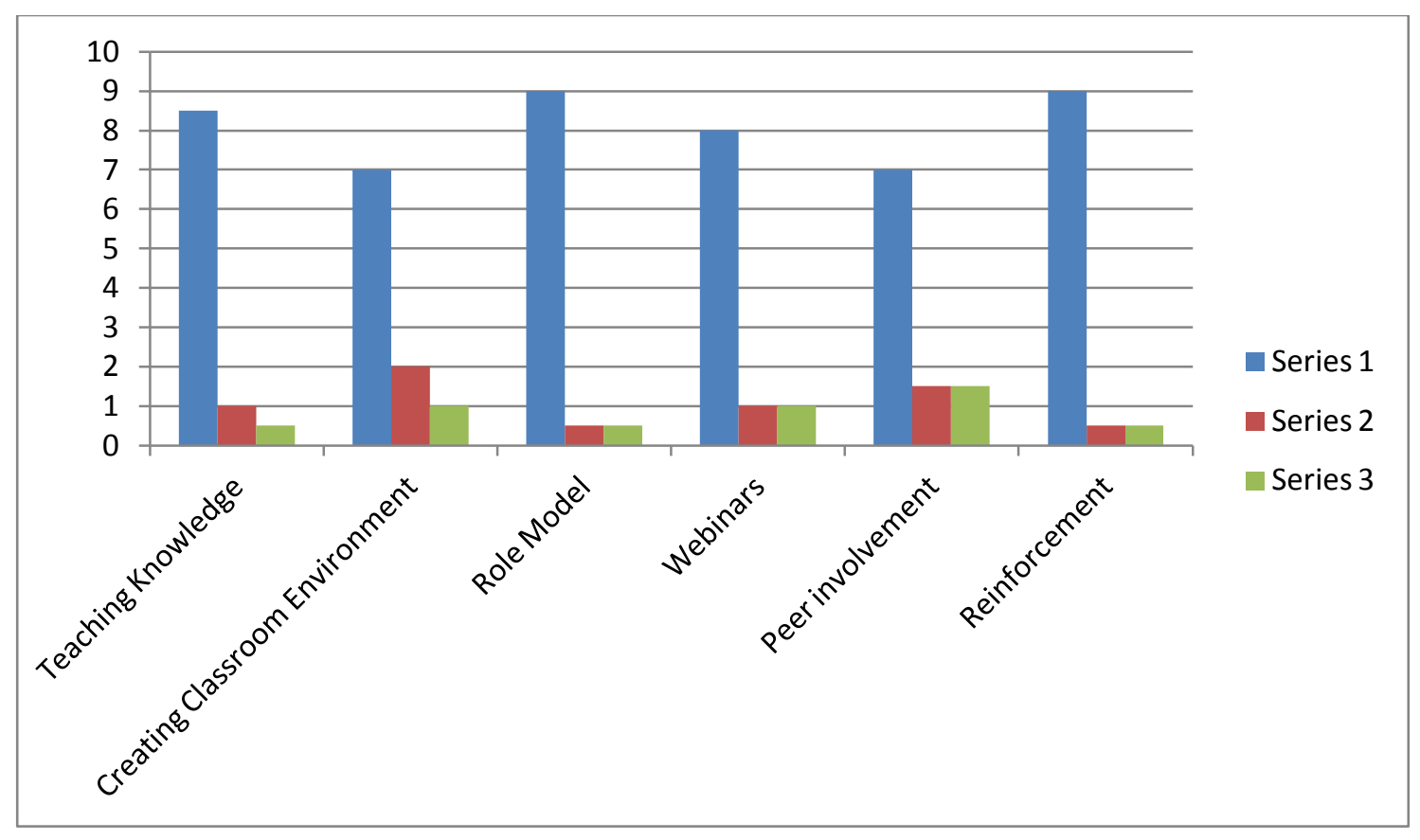

Role of an EFL teacher

\section{Conclusion}

The present work offers contributions to the online literature language learning from the learner's viewpoint in EFL context. Due to the COVID-19 pandemic, EFL teachers performed online learning via series of activities varying from testing the participation of the students to providing score on the work of the students synchronously or asynchronously, based to each school program. Various software and frameworks were used to carry out online learning, varying from the learning management framework to external tools. Nonetheless, a number of issues came from the students, the instructors and the staff. As a result, online learning is not going well as it lacks planning and preparation. Planning and training for improved online learning in the future will eventually be undertaken, as online learning takes more time to be properly trained and equipped than face-to - face lessons. The teachers have to be educated and trained with adequate information and skills to optimize their online learning activities. To develop their information literacy and correct their misperceptions about online learning, the students need to be made comfortable with online learning. Future teacher curriculum and preparation will require the application of language learning technologies, technology-enhanced language learning, and language literacy knowledge and networking technologies. More research is urged to examine the online EFL learning habits in the sense of low technology and the requirements of instructor professional growth in language learning technology incorporation.

Based on the study findings above, it can be inferred that the perspective of the learners on online learning shows that in the middle of the COVID-19 pandemic everything is fine. They saw online schooling as being really effective in the midst of a pandemic. Not only does this study conclude that online learning is better in the wake of the COVID-19 pandemic, it also shone the light on the quality of internet connectivity, financial problems and adoption of online learning. 
7 | Problems and Challenges Faced by EFL Students of Saudi Arabia during COVID-19 Pandemic

In terms of financial concerns, at the state of the learners, they expect lecturers can allow use of facilities such as free Messenger application in the online learning framework. Being a teacher we should create online demos showing them how to access and use the Learning Management System. Invite them to a new webinar on eLearning, where they will step through the process. ELearning is positive news but at its initial stage it poses certain threats to students. Change in attitudes and technological literacy would help them gain confidence to be successful with a positive vibe in their courses.

\section{References}

Cao, W., Fang, Z., Hou, G., Han, M., Xu, X., Dong, J., \& Zheng, J. (2020). The Psychological Impact of the COVID-19 Epidemic on College Students in China. Psychiatry Research, 287, 1-5. https://doi.org/10.1016/j.psychres.2020.112934.

Creswell, J. W. (2012). Research Design: Qualitative, Quantitative and Mixed Methods Approaches, ( $4^{\text {th }}$ edition), California: Sage Publications.

White, C. (2008). Innovation and Identity in Distance Language Learning and Teaching. Innovation in Language Learning and Teaching, 1(1), 97-110. https://doi.org/10.2167/illt45.0. 